\title{
Theoretical Perspectives of How Digital Natives Learn
}

\author{
Dr Charles Kivunja $^{1}(\mathrm{PhD})$ \\ ${ }^{1}$ Senior Lecturer in Pedagogy and Educational Leadership, Researcher: Embedding Social Media Technologies in \\ Pedagogy, Manager Leximancer Qualitative Software, School of Education, The University of New England, \\ Armidale, 2351, New South Wales, Australia \\ Correspondence: Dr Charles Kivunja, Senior Lecturer in Pedagogy and Educational Leadership, School of Education, \\ The University of New England, Armidale, 2351, NSW, Australia. Tel: 61-412-466-184. E-mail: \\ ckivunja@une.edu.au; c.kivunja@bigpond.com \\ Received: January 5, 2014 \\ Accepted: January 20, 2014 \\ Online Published: January 22, 2014 \\ doi:10.5430/ijhe.v3n1p94 \\ URL: http://dx.doi.org/10.5430/ijhe.v3n1p94
}

\begin{abstract}
Marck Prensky, an authority on teaching and learning especially with the aid of Information and Communication Technologies, has referred to $21^{\text {st }}$ century children born after 1980 as 'Digital Natives'. This paper reviews literature of leaders in the field to shed some light on theoretical perspectives of how Digital Natives learn and how we can use that knowledge to facilitate learning by Digital Natives. To locate this understanding within the context of general Educational Theory, the paper first presents a brief historical review of the foundational educational theories on how people learn. It then discusses some of the contemporary theories on how Digital Natives learn. Out of these two bodies of knowledge the paper synthesizes an understanding of principles, strategies and practices that we could use to effectively teach Digital Natives and facilitate their learning. It is my hope that this review will help readers develop a deeper understanding of how learners of the digital generation learn and how we can design our pedagogical principles and practices to better meet the needs of the digital learners in our teaching contexts today.
\end{abstract}

Keywords: Behaviorism, Cognitivism, Connectionism, Constructivism, Digital fluency, Digital immigrants, Digital natives, Educational theory, Instructional model, Interactive computer-mediated methodologies, Pedagogy, Scaffolding, Schema, Zone of proximal development

\section{Importance of Understanding who Digital Natives are and Theorising How They Learn}

In his article entitled, Digital Natives Digital Immigrants Part 2: Do They Really Think Differently? Prensky (2001a, p. 1) who has written many books and numerous essays on learning and teaching, particularly with regard to learning and teaching using Information and Communication Technologies (ICT) raises this question which lies at the very heart of our pedagogical attempts to understand and theorize how Digital Natives think and learn. In answering this question in the affirmative, Prensky lays a basis for intelligent debate on this relatively new area of educational theory. A learning theory is simply an attempt to describe or explain how people learn. If we accept that our role as pedagogues is to facilitate learning for our students, then we should appreciate that it is incumbent upon us to develop a good understanding of how they learn, as this will inform our pedagogical practice so that we can be more effective teachers by maximizing their learning. In our attempts to understand how children learn, we are guided by the foundational theories of learning advanced by the founding fathers such as Piaget, Vygotsky, Skinner, Bruner, Bloom, Gardner and de Bono, to name but a few. Whereas these theories have served us well, it is noteworthy that they all evolved before the digital era and this leads to questions as to whether these theories hold true for the Digital Natives as they did for the orthodoxy learners of the pre 1980s era? This paper sheds some light on this question. It starts with an articulation of who the Digital Natives are. It then presents a quick review of literature on some of the foundational educational theories of learning before it reviews the more contemporary perspectives on how Digital Natives learn. Out of these two bodies of knowledge, the paper synthesizes principles, strategies and practices that can inform our pedagogical practices to facilitate learning by Digital Natives.

\subsection{Digital Natives and Digital Immigrants: Who are They?}

In his seminal article, Digital Natives, Digital Immigrants Part 1, Prensky (2001b, pp. 1-3), introduces to educational theory two new terms that he coins as "Digital Natives" and "Digital Immigrants". According to his explanation Digital Natives are the children who have grown up into a world surrounded by and using computers, videogames, digital music players, video cams, cell phones, and all the other modern technological toys and tools. He says that they 
are the product of the new culture that has emerged as a result of the aggressive penetration of digital technology in the lives of young people born since the last two decades of the $20^{\text {th }}$ century. So, we can take 1980 as the birth date of Digital Natives. He justified this label with the explanation that they "are all 'native speakers' of the digital language of computers, video games and the Internet". Consequently, they have the skills for digital fluency. In contrast, Prensky (2001b) characterizes as "Digital Immigrants" (p.3) people, born before 1980 and therefore when it comes to using technology they are in the process of learning a new language, - a process that is typical of all immigrants in their new country.

Other leaders in this field have used different terms to refer to Prensky's Digital Natives. For example, Tapscott (1997) referred to them as the "Net Generation" or "Net Geners" and backdated their date of birth to 1977. Later, (Tapscott, 2009, pp. 11 - 20), he described them as "the children of the post-World War II generation, called baby boomers in the United States, Canada and Australia. The proverbial baby-boom 'echo' generation ... The Echo Boomers. ... The first generation to be bathed in bits. They assimilated technology because they grew up with it. For many Net Gen kids, using the new technology is as natural as breathing. To them technology is like the air". Howell (2012) has referred to them as the "Gen C, Gen I, Net Gen, Gen Y, Gen Z and Internet Generation" (p. 6). Jukes, McCain and Crockett (2010) refer to these Digital Natives simply as the "Digital Generation".

\subsection{Importance of Educational Theories of How Digital Natives Learn}

Teaching learners without a firm grasp of how they learn is like trying to erect a building on shifting sand. Another helpful analogy is that it is like embarking upon a long and detailed journey without a well planned and articulated itinerary, some GPS device like a smart phone, or a roadmap. For without a well planned itinerary or road map, how do we know where we are going? And if we don't know where we are going, what chance do we have of getting there? These simplistic analogies serve to emphasize that an understanding of learning theories is crucial to effective teaching because theories help us to understand how learners make sense of what they come in contact with, how they construct new knowledge, build on their current schema and apply what they have learnt to further their understanding of new ideas and concepts. Concepts and principles espoused by different theories have important implications for our understanding of how people learn and how best we can facilitate such learning. They can be a great help in our pedagogical practices including planning curricula, organizing teaching and assessment. If we accept that our role as pedagogues is to facilitate learning for our students, then we should appreciate that it is incumbent upon us to develop a good understanding of how they learn, as this will inform our pedagogical practice so that we can be more effective teachers.

\section{A Historical Perspective Of Educational Theories on How People Learn}

\subsection{A General Spectrum of Theories of Learning}

As pedagogues, our principles and practices are informed by many learning theories bequeathed to the profession by the founding fathers of educational theories. Each such theory is an attempt to explain how people learn, an understanding of which can inform pedagogical principles and practices to maximize student learning. Whereas a wide range of learning theories have been advanced by educators and psychologists in all fields of education over the years, there is consensus that they fall into three basic categories namely: behaviorism, cognitivism and constructivism (Jobrack, 2013). The theories are often supported by an instructional model which provides a kind of scaffolding that pedagogues can apply to enable their students extend their learning beyond what they could learn independently, along the postulates of the theory. In the following subsections, I review briefly, the key tenets of theories that fall into each of these three broad categories.

\subsubsection{Behaviorism}

Briefly, the behaviorism theory of learning, which is most widely attributed to American psychologist and behaviorist scholar Barrhus Frederic Skinner (1953) postulates that learning occurs through a process of events happening at the same time. It focuses primarily on the relationship between the environment and behaviour and sees learning as the result of forming connections between stimuli from that environment and related responses. Motivation to learn is driven by rewards and punishments (Bransford, Brown and Cocking, 2000). An instructional model that was considered to be a good scaffold for a behaviorist approach to teaching was developed by Gagne (1977) and consisted of the following nine steps:

\section{Gaining attention}

2. Expectancy: Informing the learner of the objective

3. Memory retrieval: Stimulating recall of prerequisite learning 
4. Presenting stimulus materials

5. Providing learning guidance

6. Eliciting performance

7. Providing feedback

8. Assessing performance; and

9. Enhancing retention and transfer to the job.

\subsubsection{Cognitivism}

In contrast to behaviorism, rather than focus on the relationship between the environment and behaviour, cognitivism theorists instead focus on the relationship between the learner and the environment. Their central proposition is that learning occurs as individual learners think and actively participate in what is happening in order to learn. They argue that the learner's current schema needs to be activated so that the learner may organize new information to make sense in light of prior knowledge. Individual learners' current levels of knowledge, experiences and skills have a profound impact on the way the learner makes meaning of the environment and therefore what he or she learns from his or her interaction with the environment. Thus, their ideas are very similar to those of constructivists and, as I discuss below, several theorists, including Piaget, Vygotsky and Bruner, that wrote on cognitivism, also became very well known for their contributions to constructivism. One instructional model that was developed to scaffold learning along cognitivism comprises the following six stages (Harris \& Graham, 1999).

1. Develop and activate background knowledge, including skills and knowledge

2. Discuss the strategy, to promote active involvement and ownership of the strategy

3. Model the strategy, to demonstrate how to learn and illustrate the thought process of a skilled learner

4. Memorize the strategy, so that students know and understand what is involved with each step in the process

5. Support the strategy, using scaffolding to promote a transfer of strategy performance from teacher to student; and,

6. Observe independent performance, to demonstrate use of the strategy for improved academic performance.

\subsubsection{Constructivism}

Constructivism theories of learning, as will be discussed further below, are identified most widely with cognitive psychologists Jean Piaget (1923) and Lev Vygotsky (1978). These theories postulate that learners construct knowledge and meaning from their experiences. Vygotsky in particular introduced the concept of Zone of Proximal Development (ZPD) to emphasize that there is a gap between what an individual learner can achieve on their own and what they can attain when their full potential is enhanced through support given by a more capable individual. Many instructional models have been developed to scaffold constructivism. Examples include inquiry-based learning, active learning, experiential learning, discovery learning, knowledge building and the $5 \mathrm{E}$ instructional model (Jobrack, 2013, p. 4). Of these, the 5E instructional model was developed by Rodger W. Bybee (Bybee et al., 2006) in collaboration with six of his science colleagues at the Colorado Springs Biological Science Curriculum Study (BSCS) educational centre who postulated that to maximize students active learning and construction of knowledge, we should give them opportunities to be involved in five key elements of constructivism:

\section{Engage}

2. Explore

3. Explain

4. Elaborate; and,

5. Evaluate.

This $5 \mathrm{E}$ instructional model is a learning cycle based on a constructivist view of learning, with each of the 5Es describing a phase of involvement which seeks to maximize active learning. Outside science, this model was applied and made popular in pedagogy by Jerome Bruner (1966) and I will return to it below to highlight its application in education and its implications in helping Digital Natives maximize their learning.

\subsection{Specific Theories of Learning}

In How People Learn the National Research Council (NRC, 1999) of the USA presented a comprehensive summary 
of decades of research about how people learn across a wide range of disciplines. While their synthesis covered a wide range of educational theories it in the main found consensus on three foundational propositions about how learners learn (NRC, 1999, p. 160). First, for students to learn they must be interested and engaged in what they are learning and find it useful and meaningful. Second, students must be actively involved in the process of teaching and learning, comparing new information to previous ideas, constructing new understandings, and changing their own minds about how the world works. Third, students need opportunities to apply what they have learned to new situations, to check the completeness of their understanding and to evaluate their own learning for themselves. These basic propositions are reflected in several of the theories of learning that I review briefly here. In this section, I review theories of the early leading theorists whose key contributions to an understanding of how learners learn were made before computers had made inroads into mainstream teaching and learning. I limit my brief review to the three constructivist theorists that I consider foundational to pedagogical practice and which I teach my pre-service teachers, namely, Jean Piaget (1896 - 1980), Lev Vygotsky (1896 - 1934) and Jerome Bruner (1915-).

\subsection{Piaget $(1896-1980)$}

One of the founding fathers of learning theories was the Swiss psychologist Jean Piaget to whom is attributed the cognitive developmental theory that every individual passes through four successive stages of intellectual development namely, Sensori-motor: $0-2$ years; Preoperational: $2-7$ years; Concrete Operational: $7-11$ years and Formal Operational: 11 years and above. Piaget (1923) believed that humans are naturally curious about their environment and constantly explore it in their attempts to make sense of it as they internalize knowledge across these stages. He believed that they need to construct meaning of the world for themselves and accordingly, his four-stage theory became known as the epistemological theory of constructivist learning. I review this theory here briefly because it has direct implications for the role of digital technologies in learning which is the primary focus of this paper.

Piaget's theory of constructivism posits that learners gain knowledge and construct meaning from the interaction between their own experiences and ideas (Piaget, 1923). He based his understanding of cognitive development and of how learners think and understand the world around them on observations of children and adolescents whom he studied as they solved problems he set them in natural situations. He concluded from his studies that learners construct new knowledge from their experiences through two processes, which he called 'assimilation' and 'accommodation'.

To explain assimilation, Piaget (1954) argued that learners approach learning with an existing schema and when they interact with new experiences and ideas they organize the new information and add it to their existing schema in a process of assimilation. Assimilation thus leads to learning because the learner extends his or her existing way of thinking to a new schema which makes room for the new knowledge. However, when new information cannot be absorbed into the existing schema because it contradicts the learner's existing way of thinking, there is what he called 'cognitive conflict'. Piaget called this mismatch a cognitive disequilibrium but rather than see it as a constraint to learning, he argued that in this case, the learner doesn't simply reject the new experience but can modify his or her current way of thinking and reframe his or her mental model of reality through a process of accommodation by which the learner opens up and accepts the new experience. This leads to learning because the learner adopts a new way of thinking to accommodate the new information. He or she raises his or her way of thinking from a lower level schema to a higher level schema. Such accommodation leads to learning as the learner advances from cognitive disequilibrium to cognitive equilibrium with an extended schema. These two processes - assimilation and accommodation - lead to what he called 'adaptation'. According to Piaget (1971) adaptation was the basic life process that helped a person adjust to the demands of the environment. Thus Piaget conceptualized learning as a process of continuous interaction between the learner and the environment. So, his theory is undergirded by the understanding that learners construct meaning from their experiences gained as they interact with the environment. This interaction entails active engagement of the learner, hence the constructivist proposition that children learn best when they are given opportunities to be actively involved in the construction of knowing - a proposition which, as I will argue later in this paper, undergirds the way Digital Natives learn.

\subsubsection{Vygotsky (1896 - 1934)}

Focusing his intellectual development studies on the social environment of the child at about the same time that Piaget was focusing on the child's individual exploration and discovery, a Russian cognitive psychologist Lev Vygotsky (1978) produced what became known as the developmental theory of social constructivism. Vygotsky's key proposition was that children's cognitive development is influenced most by people, especially parents, teachers, and mentors in the child's social environment. He argued that it is the collaborative interactions between a learner 
and members of his or her immediate society that enable the learner to make meaning of their world in their cultural setting. He articulated the importance of this relationship in his words, "In the process of development, the child not only masters the items of cultural experience but the habits and forms of cultural behaviour, the cultural methods of reasoning" (Vygotsky, 1929, p. 415). In spite of this shift in focus from an individual learner's exploration and discovery to the social environment as the driver of cognitive development, Vygotsky, like Piaget, also believed that the individual learner needs to personally make sense of ideas, concepts and skills of the culture in which they are immersed. The key difference between Piaget and Vygotskian constructivism is that it is individualistic according to Piaget but societal or cultural (co-constructivism) according to Vygotsky.

Another aspect of Vygotsky's theory that is very relevant to the focus of this paper is what he called the Zone of Proximal Development (ZPD). He explained the ZPD as the level of competence on a task in which a learner cannot yet master the task working by himself/herself but can complete the task successfully if given appropriate support by a more capable mentor.

These two dimensions of Vygotsky's cognitive development theory have significant implications for us as we try to understand how learners learn. For a start, one of the key implications of Vygotskian social constructivism is that the social-cultural-technological environment within which a child is immersed has a profound influence on their cognitive development. This theoretical perspective underpins my discussion in sections 3 to 5 of this paper, of how Digital Natives, born into a world of computers and growing up with the smart phone and eTablets construct meaning of the world around them. Secondly, learners can extend their ZPD with the assistance of anyone who recognizes their current learning need and is capable of lending the needed support. That person does not have to be a qualified classroom teacher or academic pedagogue. It could be another child, another learning adult or peer, or a parent. This theoretical perspective informs our understanding of the role of social media in facilitating learning among Digital Natives through, for instance, the use of Peer Learning Networks.

\subsubsection{Bruner (1915 - )}

Now aged 98, Jerome Seymour Bruner is a cognitive psychologist who has made significant contributions to human cognitive psychology and cognitive learning theory in educational psychology, as well as to history and to the general philosophy of education. In The Process of Education, (Bruner, 1960) he theorized that intellectual development involves four components, namely curiosity and uncertainty, structure of knowledge, sequencing and motivation. In Toward a Theory of Instruction, Bruner (1966) identified four principles that influenced the developmental process of children as (Marsh, 1996, p. 22):

- Increasing independence of responses from stimuli accompanies intellectual growth. Over a period of time, children are no longer under rigid stimulus control.

- Each child develops an internal information-processing and storage system to represent the world. To grow developmentally, children must develop representations of the world beyond immediate sensory data.

- Language is the key to cognitive development.

- Tutors and learners need to systematically interact with each other if cognitive development is to occur.

Like Piaget (1923), Bruner also identified stages of cognitive development, but he categorized these into only three and unlike Piaget did not believe that they were successive or hierarchical. They could be employed by the learner at any time in isolation or in conjunction with each other simultaneously. His three stages were the Inactive stage, during which the child learns by doing; the Iconic stage, during which children use imagery based on sensory impressions but not language and the Symbolic stage was the final stage during which children gain an understanding of concepts and ideas through the use of symbol systems including language, logic and mathematics (Marsh, 1996, pp. 22 - 23). Like Piaget and Vygotsky, Bruner also emphasized the importance of the constructivist principle of active learning. It was this emphasis that led him to embrace the $5 \mathrm{E}$ instructional model and to apply it widely in educational contexts as discussed below.

\section{Bruner's Application of the 5E Instructional Model in the General Philosophy of Education}

In accordance with Bybee et al. (2006), and his colleagues who designed the 5E instructional model for teaching science, Bruner (1966) called the first phase of the learning cycle Engage. The purpose of the educator in this phase of teaching is to peak student interest and attention and get them personally involved in the topic of the lesson. The educator gets learners engaged through asking questions that enable him to access the learners' prior knowledge, applies strategies that stimulate their curiosity, encourages them to ask 'why' type of questions and motivates them to want to learn by helping them make connections between past and present experiences to organize their thinking to 
focus on the learning outcomes for the particular lesson. An illustration of how engagement can be achieved in an English lesson is evident in this example in which learners are given a Journal Prompt along the following quote of President Franklin Roosevelt and then set questions to engage their thinking:

Happiness is not the mere possession of money; it lies in the joy of achievement.

1. What is Roosevelt saying in this quote?

2. Do you agree with him? Why or why not?

3. What are your thoughts about money and happiness, do you think it is necessary for happiness?

4. What if a large group of people in one place or a country lack the money they need to survive; how does this affect their happiness?

5. What do you think a government should do if the people in their country do not have the money they need for survival?

The questions will of course vary depending on subject and curriculum but they are intended to stimulate learners' thinking, provide a focus for the students' attention in the lesson and to give the teacher the opportunity to gain an understanding of the children's initial conceptions or prior knowledge. In general, they should reveal what the students already know about the topic, what they want to know and introduce what in particular they will explore.

In the second phase of the 5E instructional model, Explore, Bruner (1966) explains that the purpose of the teacher is to get students involved in the topic by providing them with a chance to use prior knowledge in the investigation of an issue or a problem so as to find the solution for themselves. To facilitate this, the teacher gives learners activities requiring them to work individually or cooperatively on a problem or an issue, to identify existing concepts, understandings, perceptions or misconceptions and to come up with questions and ideas which challenge their current thinking and help them derive their own solutions and decisions as $\mathrm{s} / \mathrm{he}$ facilitates conceptual change among the learners. Such exploration gives students an opportunity for metacognition as they think about their thinking on the task given. Such exploratory metacognition challenges learners, "increases their interest, elevates their need to know and to ask sensible questions about what they don't know and can't answer by themselves" (Tanner, 2010, p. 161). This phase is seen as having potential to encourage constructivist learning among learners because the teacher sets the scene for learning and encourages the learners to work on their own or collaboratively without direct teacher instruction.

In Explain, the third phase, the teacher encourages students to explain in their own words, their understandings of what they have been engaged in and their exploration experiences in the learning cycle. This is the phase where the teacher can explicitly introduce new concepts, definitions or themes and give learners the opportunity to explain their understanding of those concepts. In this phase the teacher clears any confusions and clarifies any misunderstanding on the part of the learners. The explanations can be assisted with a whole-class discussion in which the teacher raises questions which when answered and explained by students help them develop a deeper understanding. This way, "the explanation phase involves active participation by both instructor and students" (Tanner, 2010, p. 161) as students are given a chance to take what they have learned and figure out what it really means.

This phase is also student-centred because students are given opportunity to listen critically to the explanations given by the teacher and their peers, raise questions about what they hear and add their own explanations so as to engage in active learning. Clarke (1994) suggested that the Explanation phase might even include a variety of peer teaching and learning activities. The explanation can be simple or complex depending on the stage of the learners. For example, in a high schooling stage, students could be asked to explain how people in a democracy exercise their discontent and effect change. In contrast, in a primary classroom, children could be asked simple questions to simulate their families' experiences such as:

- What groceries did your family purchase over the last four weeks?

- What changes in grocery purchases did you family make over that period?

- Can you tell us why those changes were made?

- How did those changes affect what you were able to bring to school in your lunch box?

- How did those changes affect other members of your family?

The fourth phase of the 5E model is Elaborate but it is also called Extend (Barufaldi, 2002) or Expand (Vonnie, 2010). The purpose of Elaborate is to allow students to use their new knowledge and continue to explore its implications by applying it to new but similar situations and carrying out analyses. Such exploration gives learners 
the opportunity to develop a deeper and broader understanding of what they are learning and to extend their skills. Like all the other phases of the 5E model, Explore involves learners in active participation as they apply knowledge to other situations, consider the effects of their knowledge, apply what they have learnt to their own world and analyze, compare and contrast what they have learnt.

The Elaborate phase is fully consistent with constructivism as it gives learners the opportunity to use previous information to investigate new ones, propose solutions and reach their own conclusions through being involved in new experiences. They can practice learned skills, refine them and change their behavior. The teacher asks learners 'what if' and 'why' type of questions which challenge and encourage the learners to extend their understanding into new contexts and then apply their new understandings and skills to deepen their knowing.

The final phase of the 5E model is Evaluate. In it, students are given opportunities to reflect and to assess their own understanding and to demonstrate evidence of mastery or accomplishment of concepts and skills (Barufaldi, 2002). In this phase, both students and the teacher determine how much learning and understanding has taken place and whether the learning outcomes have been achieved; thus giving learners the chance to evaluate their own progress. The teacher may evaluate the learners' achievement by asking open-ended questions which require higher-order critical thinking on the part of the students.

The evaluation can be implemented using a wide range of tools. For example, it could involve outcomes-based rubrics, structured checklists, student interviews, portfolios, project and problem-based products, or embedded assessments tasks (Vonnie, 2010). The assessment could be through self-assessment, peer assessment, teacher assessment, observation or performance assessment. As students evaluate their learning they have opportunity to ask questions that encourage their engagement in future learning.

Although the 5E instructional model was developed primarily to assist science teachers plan and teach their lessons more effectively, its ubiquitous use in educational contexts outside science has shown that it is highly applicable to an understanding of how children, students and adults learn at all cognitive levels (Bruner, 1966). Within the five easily memorable words, each of which begins with the letter E, are embedded activities and learning processes that lie at the very foundation of constructivist teaching and learning. For example, each of the 5Es puts the responsibility for knowledge construction in the hands of the learner, not the teacher (Piaget, 1950, Vygotsky, 1978). It has thus proved popular in pedagogical practice and represents and instructional model that promotes active learning.

\section{Contemporary Theories on How Digital Children Learn}

In this section I review the pedagogical perspectives of some of the leaders in the field that have emerged as educators have engaged with ICT and tried to explain how the use of technology, driven by computers and digital technologies, impacts on behaviors, thinking and learning by Digital Natives. Although these perspectives are strictly speaking not 'theories', they have made significant contributions to our understanding of this relatively new area, of how Digital Natives learn, and consequently on how we can facilitate their critical thinking, problem-solving and construction of knowledge.

\subsection{Marc Prensky - 2001}

In Digital Natives, Digital Immigrants, Part 1, Prensky (2001b) argued that the reasons why there was an apparent decline in education in the USA in the last decades of the 20th century lie primarily in the advent of digital technology which had been widely embraced by American students, outside school, across all ages of learners from K-12 through to college, but not applied in the classroom. As evidence of this phenomenon he submitted that whereas:

Today's average college grads have spent fewer than 5,000 hours of their lives reading ,... by the time they are 21 they will have played more than 10,000 hours of video games, sent and received 250,000 emails and text/instant messages, spent 10,000 hours talking on digital cell phones. ... Computer games, e-mail, the Internet, cell phones and instant messaging are integral parts of their lives (p. 1).

He proposed that as a result of this exposure to digital technologies and devices of the digital world, children of the digital era think and learn differently from their predecessors and to articulate that difference he called these "new" students "Digital Natives" - a term, though not universally accepted, is widely used today. Reasoning that the experiences we grow up in shape our behaviors and how our brain functions, he proposed "we can say with certainty that the thinking patterns of the Digital Natives have changed".

Referring to people born before the advent of the digital era as Digital Immigrants, Prensky (2001b, p.3) went on to explain further the decline in American education by asserting that "the single biggest problem facing educators 
today is that our Digital Immigrant instructors, who speak an outdated language (that of the pre-digital age), are struggling to teach a population that speaks an entirely new language". As a consequence, he argued, schools were failing to help children learn because the Digital Natives were being taught by unintelligible Digital Immigrants that taught with a foreign accent that could hardly be understood by the Natives.

Another reason that Prensky (Ibid, p.4) proposed for the failure of American schools to help Digital Natives learn was that the Digital Immigrant teachers neither had nor appreciated the new skills that the Natives had acquired as a result of their immersion into the digital reality. Continuing to teach in the traditional way of talking or lecturing and presenting material using step-by-step logic targeted to memory recall tests, the Digital Immigrants failed to appreciate how the Natives learn and they bored them to disliking school. Simultaneously, the Digital Natives feel that "their Digital Immigrant instructors make their education not worth paying attention to, compared with everything else they experience" (p. 4). The product of this Immigrant/Native divide was frustration on either party as the Digital Immigrants failed to be effective teachers and the Digital Natives failed to learn from their unintelligible teachers. Prensky (Ibid) categorically states that Digital Natives learn differently than children of the pre-digital era.

\subsection{Kelly, McCain and Jukes - 2009}

In Teaching the Digital Generation Frank Kelly, Ted McCain and Ian Jukes (2009) express views that are very much in agreement with Prensky's perspectives on how digital technologies have influenced the behaviors, thinking and learning of Digital Natives. They say that:

The world we live in has fundamentally changed. Our students have moved into the information Age... The learning styles of today's digital kids are significantly different than those for whom our high schools were originally designed. They work, think, and learn differently ... and our schools ... and instruction primarily based on teachers talking in classrooms, textbooks, memorization and content-based tests, ... are becoming increasingly out of sync with the world around them (Ibid, p. 9).

These leaders in the field argue that this represents a mismatch between schools and Digital Natives and the old, Industrial Age high school is not suited to meet the learning needs of $21^{\text {st }}$ century students. As evidence that the industrial model high school does not help Digital Natives learn, they cite examples from USA high schools where about one third of all students fail to graduate. This ratio is worse in urban areas with low social economic ranking where more than $50 \%$ fail to graduate (Ibid, p. 5). These authors are so concerned about the failure of high schools organized on the old Industrial Age model to meet learning needs of Digital Natives that they express the fear that such schools will not survive for another decade.

So, why is it that schools organized on the orthodoxy Industrial Age model are not meeting the learning needs of Digital Natives? In answering this question they say:

Quite simply, what's wrong is that the world has changed and schools have not. Capitalizing on the astounding power of new electronic tools, the world outside education has moved beyond the idea of mass production that was the hallmark of Taylor's assembly-line approach to life. We are now in the beginnings of a whole new era of technologically driven mass customization and the age of the individual (Ibid, p. 13). The sudden shift to the online digital world has rendered that experience irrelevant to modern students (p.18).

Whereas in the old way of learning students relied on the teacher and school as the primary sources of educative information, accessible only while at school, now the Internet and the world wide web provide ubiquitous sources of information to students wherever and whenever they can connect to the Internet. Therefore, digital children can learn, not necessarily by going to school but from wherever they can access the Internet whether that be their homes, their friends' places, on the bus or train. Moreover, they learn not by reading black-and-white text information but the digital tools give them access to a sensory-rich world of information made more attractive with full-color, graphics, video and stereo sound.

Thus, Digital Natives learn not from the linear, paper-based data in textbooks but from hyperlinked, random access, digital sources that are available online. They learn, not simply by reading, writing and arithmetic, but with the assistance of online cameras, simulations, games, wikis, blogs that they create. They develop skills for digital fluency rather than skills in the orthodoxy 3 Rs developed with talk, chalk and board; paper, pencil and pen. Moreover, in so doing, the Digital Natives learn by assuming responsibility for their own learning" (Ibid, p. 40) which, as discussed earlier, is a very constructivist learning philosophical proposition. What's more, this new way of learning is consistent with active learning and constructivism as represented in the application of Bruner's 5E instructional model because "more and more, technology is allowing people to have firsthand experiences of events, ... and to observe and 
manipulate natural processes. Learning about the world has become dynamic, relevant and fun" (Ibid, p. 13) making it easily Engaging, creating opportunity for Exploration, Explanation, Elaboration and Evaluation (Bruner, 1966) of what the Digital Natives access, develop and create on the world wide web. This is perhaps best articulated by Kelly, McCain and Jukes (2009, p.15) when they say:

There is an even more important aspect of the Information Age for educators to consider: the impact the online digital world is having on the thinking patterns of young people. Kids today are growing up in a radically different environment than kids did as little as 10 or 15 years ago. They have been exposed to online digital tools for their entire lives. The use of such devices as computers, wireless devices ... and a myriad of other networked digital tools and social networking software is as natural to them as breathing. They are completely comfortable with powerful software tools that allow them to ... network with others, ... write essays and reports.

They conclude that it is critical for us as educators to grasp that this digital immersion is changing the way Digital Natives think. The Digital Natives think and therefore learn differently than non-digital children. For example, they process information faster than the older generations and manage high-speed information better. These authors say that in fact, brain research has revealed that the constant exposure of the brains of Digital Natives to digital bombardment has "actually altered the neural pathways in kids' brains" (Ibid, p. 15).

These authors argue that most schools are failing to help Digital Natives learn because in the main, they have not changed the way they organize instruction for children. They have operated along what they (Kelly, McCain \& Jukes, 2009 , p. 34) call the TTWWADI approach whereby they have continued to do what they do because That's The Way We've Always Done It. While doing things the way we have always done them is not necessarily wrong, the problem is that such an approach alone fails to enhance learning among Digital Natives and to prepare them for the digital workplace in which they should be productive citizens, which, according to Fullan (2001) is the moral purpose of education. The consequences of this disconnect between Digital Natives and schools operating along the TTWWADI approach was well articulated by Bill Gates when he said:

America's high schools are obsolete. ... By obsolete I mean that our high schools, even when they're working exactly as designed, cannot teach our kids what they need to know today. Training the workforce of tomorrow with the high school of today is like trying to teach kids about today's computers on a 50-year-old mainframe. It's the wrong tool for the times (Gates, 2005).

\subsection{Don Tapscott - 2009}

In Grown Up Digital: How the Net Generation is Changing Your World, - a book that arose out of a \$4 million research project that investigated many experiences of Digital Natives, - Don Tapscott (2009) presents the findings of his team. The findings are well informed because they are based on the results of interviews of a global sample that consisted of 7,685 Digital Natives drawn from twelve countries, aged 13 to 20 years that he called the Net Generation or Net Geners in his earlier book (Tapscott, 1997). In his words, the findings are the result of "the most comprehensive investigation of the digital generation ever done" and were aimed at "finding out the truth about this generation" (Tapscott, 2009, p.5). The findings, inter alia, make a significant contribution to our understanding of how Digital Natives "interact with technology and how that might be changing the way in which they learn" (Ibid, p. 1).

Tapscott's research found that Digital Natives have reflexes that are tuned to speed and freedom, and they are smarter, quicker, and more tolerant of diversity than Digital Immigrants and they are disposed to transform every aspect of modern life including the way institutions teach them. In addition to the eight attributes of Digital Natives listed first in the summary below, - attributes that Tapscott (2009, p.34) called "the Net Generation Norms" I summarize below, some of the many characteristics that Tapscott found to be typical of Digital Natives and which have a bearing on how they learn and how we should teach them to facilitate their learning (Ibid, pp. 6 -131):

i. They prize freedom and freedom of choice.

ii. They love to customize things, make them their own.

iii. They're natural collaborators, who enjoy a conversation, not a lecture.

iv. They'll scrutinize you and your organization.

v. They insist on integrity and openness.

vi. They want to have fun, even at work and at school. 
vii. They have a need for speed and speed is normal for them.

viii. They are innovators and for them innovation is part of life.

ix. They instinctively turn first to the Net to communicate, understand, learn.

$\mathrm{x}$. They are constantly creating or changing online content.

xi. They seem to feast on technology and have an appetite for all things digital that is sometimes mind-boggling.

xii. They seem to lack long attention spans, at least when it comes to listening to lectures.

xiii. They show signs of learning differently and the best of them make yesterday's cream of the crop look dull.

xiv. Growing up digital has had an impact on how they think and even changed the way their brains are wired.

XV. Two of the smartest brain scientists, - Stanley Kutcher and Matthew Kutcher - conducted research which found that Net Geners' brains have indeed developed differently than those of their parents (p.29). They are wired differently from those of the previous generations.

xvi. The generation is smarter and quicker then their predecessors.

xvii. In education, they are forcing a change in the model of pedagogy, from a teacher-focused approach based on instruction to a student-focused model based on collaboration.

xviii. They use the programmable web to create their own content, collaborate with others, and build communities.

xix. They don't just take what they are given. They are the active initiators, collaborators, organizers, readers, writers.

XX. They do not just observe, they participate.

xxi. They inquire, discuss, argue, critique, investigate, seek and inform.

xxii. They search for, rather than simply look at information. This helps them to develop thinking and investigative skills.

xxiii. They care about their/, education: the vast majority thinks that having a college degree is more important today than it was for their parents.

xxiv. For once in our civilization, children are educating older people. Adults are looking to children for information and help with computer related stuff.

XXV. In Finland, the government has chosen 5,000 Net Geners to train the country's teachers in how to use computers. For the first time ever, in one domain, the students will be the teachers and the teachers the students.

xxvi. They want to learn, but they want to learn only what they have to learn, and they want to learn it in a style that is best for them.

xxvii. Sitting mutely in front of a teacher doesn't appeal to them.

Tapscott (2009, p. 122), in agreement with Kelly, McCain and Jukes' (2009) TTWWADI paradigm says that the problem with education today is that:

The Net Geners have grown up digital and they're living in the twenty-first century, but the education system in many places is lagging at least 100 years behind" (p.122). The reason many students are deserting school is because schools today still use a model of education that was designed for the Industrial Age. That model revolved around the teacher who delivered a one-size-fits-all, one way lecture. The student, working alone, is expected to absorb the content delivered by the teacher. This might have been good for the mass production economy, but it doesn't deliver for the challenges of the digital economy, or for the Net Gen mind.

Like Prensky (2001b), Tapscott (2009) asserts that schooling organized on this traditional model is failing our youth. As evidence for his assertion he cites what he calls "a massive dropout problem in many high schools in the USA", and argues that "the Industrial Age model of education is one of the key causes" (p. 122).

Although Tapscott also found that unfortunately, Digital Natives were making a serious mistake of sharing their 
personal information on social networks and that this was likely to hurt them in the future by undermining their privacy, he was very positive that the Digital Natives' ability to use tools to share information and make it flow freely would positively change life; and schools and universities would have to change to meet the demands of the Digital Natives (p. 8). Exactly how the change would occur was not yet known and this was ground for fear, myths, skepticism and uneasiness among the older generation regarding Digital Natives.

\section{Synthesis of These Theoretical Perspectives and Their Implications For Effective Ways To Teach Digital Natives}

There is consensus among the theorists reviewed here; that knowledge construction, -learning, - does not occur until the learner has internalized what $\mathrm{s} /$ he has been taught. This happens best when learners talk about what they have learnt. Doing so helps them to make better sense of it and construct a deeper understanding of what it means. The Digital Natives have grown up collaborating, sharing information and creating together online. The old way of learning along a do-it-on-your-own attitude simply doesn't make sense to them. Therefore, the old individual learning model does not help Digital Natives to learn. As Kagan (1988) argues, cooperative learning is more effective in increasing academic performance than individual or competitive learning. We should therefore take advantage of the digital technologies that Digital Natives communicate with in their daily lives and use them to communicate pedagogical content knowledge in a more engaging way.

We learn from Tapscott (2009) that an effective methodology to help Digital Natives learn is to use hands-on strategies in our teaching. Tapscott (2009, p. 138) quotes Nick Dubois who said, "the hands-on approach, with open discussion and honest critiques, is the best way of learning". Tapscott concludes by admonishing that "students won't be prepared for the world of today unless schools use technology to implement real change to their model of education (p. 144).

The review of Prensky's work clearly shows that he proposes that the way we can help Digital Natives learn is not by trying to teach them the old way. Not only would that mean that the Digital Natives would be going backwards, it might in fact be impossible because their brains have been wired differently through their persistent exposure to and living in the digital world. Moreover, as with any generation, children born into any culture learn the new language of that culture naturally easily rather than trying to learn the language of their former country. Our reminiscing about how great things were in the old country will not facilitate learning by the Digital Natives. The way to help them learn is to change the way we teach and what we teach. In sum, Prensky (2001b, pp. 4-5) suggests the following ten ways to achieve this:

- Teachers/educators should learn to communicate in the language and style of the Digital Natives.

- Educators should carefully examine the content of the "traditional" curriculum - (reading, writing, arithmetic, logical thinking, and history) and select only content that is essential to knowledge construction in the digital era.

- Educators should embed digital and technological content in their teaching. This does not mean just electronic hardware and software, but it also includes the ethics, politics, sociology, languages and other content related to these.

- Educators should learn new content and teach it using new technologies that Digital Natives are familiar with and that make sense to the Digital Natives. Computer games are a good way to achieve this.

- Educators should replace traditional pedagogical language with contemporary, computer-aided terminology, consistent with Digital Native methodology. This should be applied to all subjects and at all levels of learning.

- Educators should think deeply and research into how to use computers and electronic, digital tools in teaching in ways that help our learners to instill knowledge that needs to be internalized.

- Use the skills of our Digital Natives to guide our search for Digital Native methodologies that can help us improve our effectiveness in the teaching of all subjects and at all levels.

- Share and publicize the successes of leaders in the field of embedding technology in teaching and learning.

- Be imaginative about how you can embed "edutainment" in your pedagogy. The fact that to date such attempts have not been successful should not deter further attempts.

- Educators must realize that the Digital Immigration way is not the only way to teach; that in fact it is an ineffective way to teach; and change their methods and language to that of Digital Natives so as to reach their digital learners. 
The availability of enormous databases online that Digital Natives can access to find information and share it with their peers as they collaboratively network so that together they can meet their learning outcomes means that for us educators to be able to guide their learning, we need to be able to teach them specific strategies that they can employ to effectively navigate through such data using the new tools available today and more sophisticated ones that are emerging all the time. This does not threaten our role as educators. Rather, it challenges us to develop digital fluency so that we can facilitate our Digital Natives' learning more effectively.

We know from Piaget's (1954) theory reviewed above that learners construct meaning in new information by making a connection between the new information and what they already know. As discussed earlier, Piaget called this process of extending schema, adaptation. Along this understanding Kelly, McCain and Jukes (2009) argue that since Digital Natives have grown up in a world in which digital technologies are part of their lives, and in which, for instance using computers, surfing the net, sending emails, texting and chatting are part of their normal experiences, these technologies affect the way they think. Not only do they affect the way they think but also several aspects of their world including their behaviors, language, culture and schema. Accordingly, these authors submit that therefore, for us teachers to help Digital Natives learn, we must use examples, illustrations, and stories that come from the Digital Natives' world. This way, our teaching will become more interesting and relevant to our students because it will be linked to their real world.

In sum, for educators to transition from the traditional approach to teaching to this new way of facilitating and enhancing learning for Digital Natives, Kelly, McCain and Jukes (2009, pp. 22-23) propose that we need to do the following:

- Catch up to the digital kids: This is imperative, not optional.

- Communicate directly with the digital kids by:

- Email

- Chatting with instant messaging

- Surfing and searching the Internet

$\circ \quad$ Reading and publishing blogs

○ Texting with cell phones

- Taking and sending pictures with cell phones

- Playing electronic and online games

$\circ$ Listening, watching and creating podcasts; and,

- Engage with a whole range of other activities kids take for granted.

- Develop a relationship with the digital world of our students so we can make school relevant to them.

- Explore the digital world so to discover powerful new digital tools with which to enhance the learning experiences of the children.

- Gain new digital life experiences and use then to guide our digital native students in their construction of knowledge.

As a way of making school relevant and attractive to the Digital Natives, Tapscott (2009) advocates the "dumping of the Industrial Age model of education and replacing it with a new one, that is responsive to the educational needs of the Digital Natives" (p. 122). To achieve this paradigm shift, he recommends, in sum, the following pedagogical strategies (pp. 122 - 130):

- Instead of focusing on the teacher, the education system should focus on the student.

- Instead of lecturing, teachers should listen to students, hold conversations with them, and interact with them.

- Instead of teaching students how to memorize information, teachers should teach their students critical thinking skills.

- Instead of using the broadcast style of instruction, teachers should help their students to discover for themselves.

- Instead of delivering a one-size-fits-all form of education, school should customize the education to fit each child's individual learning styles. 
- Instead of isolating students, the schools should encourage them to collaborate among themselves and with others outside the school.

- Provide training to the Digital Natives to enable them to think creatively, critically, and collaboratively; to master the basics and excel in reading, math, science and information literacy.

- Provide training that will enable them to respond to opportunities and challenges with speed, agility and innovation.

- Teachers should use technology and embed interactive, computer-mediated methodologies in their classroom instruction.

- Teachers should introduce just-in-time teaching and learning strategies whereby the benefits of web-based assignments are combined with an active-learner classroom in which courses are customized to the particular needs of a class.

\section{Implications and Conclusion}

Educational theorists, whether behaviorist, cognitivist or constructivist, agree that an effective way to facilitate learning is to give learners the opportunity to actively engage in activities and processes that make what they are learning meaningful to them. There is consensus among the authors reviewed in this paper that the use of computers and computer-aided technologies in teaching aligns well with the behaviors, thinking and learning processes of Digital Natives. The theoretical perspectives reviewed here provide compelling wisdom that for us pedagogues to facilitate learning by Digital Natives, we should embed digital technologies in our teaching, learning and assessment. We need to acknowledge that the world as seen by Digital Natives today is very different to that we older folk grew up in. In today's 24/7/365 world, we need to embed into our pedagogical practices, strategies which will enable our students to maximize the benefits available from engagement with digital technologies. For us pedagogues of the digital age, the combination of Technological Pedagogical Content Knowledge (TPACK) as espoused by Mishara and Koehler (2006) will enhance our effectiveness in teaching Digital Natives. To the Digital Natives, digital bombardment is not a curse. It is a virtue that spices their lives, and this should include pedagogical learning experiences. While by no means suggesting that we should only teach what Digital Natives want, I draw from the theories an understanding that teaching with digital technologies that Digital Natives are familiar with will facilitate their engagement with that content and help them construct its meaning.

Theoretical perspectives of how Digital Natives learn help us to understand how we can facilitate their learning. The perspectives of the ICT authors reviewed in this paper suggest that we owe it to our students, the Digital Natives, to develop a digital pedagogy that can make their learning experiences more interesting, motivational and enriching experiences of knowledge creation. Such pedagogy does not necessarily mean that we throw the Industrial Age model out of the window altogether but rather that we need to strike a balance which enables us to utilize the beneficial attributes of specialization in combination with the individualized, critical-thinking and questioning skills that digital technologies facilitate among Digital Natives. It is my view that teaching along the TTWWADI paradigm will not enhance critical knowledge construction by Digital Natives. Rather, we need to move our teaching from the orthodoxy Vygotskyian Constructivit Paradigm to a more digital Connectivist Paradigm that is driven by computers and electronic technologies in which our Digital Natives have dexterity and fluency.

The perspectives reviewed above tell us that Digital Natives do not learn by being told what to do and memorizing the procedures needed to accomplish a task. This is how children learnt in schools organized along the Industrial Age procedures in which content recall was the measure of educational success. Such schools produced graduates that were well suited to the assembly-line, linear, logical, beginning to end sequential processes typical of Taylor's (1910) Scientific Management model that was the hallmark for the success of specialization and mass production in the Industrial Age. Digital Natives learn by finding meaning in the information they access and seeing its significance in the big picture of their real lives. They need "to take that newfound knowledge and apply it to solve problems and accomplish a task" (Kelly, McCain and Jukes, 2009, p. 20). This means that we must change the focus of what we teach and how we teach so that Digital Natives will acquire the higher level, big-picture thinking skills that will enable them to be effective contributors to the economy of the digital world. These authors conclude with a dire warning that "Schools that continue to teach to an Industrial Age way of life will be dismissed outright by their clientele of $21^{\text {st }}$-century digital kids" (p. 21). While one might see this warning as extreme or one-sided, it nevertheless alerts those of us in education of the need to search for ways in which the use of technology will make us more effective pedagogues in the classroom or lecture theatre of Digital Natives.

A significant amount of literature supports the theoretical perspectives advanced by Prensky and the other ICT authors 
reviewed in this paper. For example, McNierney (2004, p. 65) emphatically suggests that teacher educators "must model instructional methods which help future teachers understand that technology-based instruction is no longer an option. It is a requirement". In justifying why we should embed technologies in teaching Howell (2012) suggests two types of arguments which she characterized as social imperatives and pedagogical imperatives. Among the former, she identified the expectations of students, parents, employers and the wider community. For the latter, she identified what Sabelli (2008) called "constructionism", which is the understanding that learners construct meaning of what happens around them not only through active engagement but when that engagement results in the creation of a product that is meaningful to them. This is the type of learning advocated by Prensky, and the other ICT theorists reviewed here in that they all strongly suggest that Digital Natives don't just assimilate information but they use technology to draw their own conclusions through creative manipulation of the information.

As all the ICT theorists reviewed here have suggested, the brains of Digital Natives are wired differently. For example Prensky (2001a, p.5) proposes, their brains are used to the "twitch-speed, multitasking, random-access, graphics-first, active, connected, fun, fantasy, quick-payoff world of their video games, MTV, and Internet". As a result Digital Natives very easily find most of what is offered in the orthodoxy, Industrial Age classroom way of teaching, boring and possibly irrelevant to their real world outside the classroom. Therefore, to engage Digital Natives and keep them interested so we can help them learn, we must speak their language. This means that the Digital Immigrant teachers need to rapidly acquire $21^{\text {st }}$ century digital skills so they can catch up, and hopefully keep pace with their Digital Natives.

It is clear from the reviews above that our educational institutions need to change so as to meet the learning needs of the Digital Natives. It is the right of every young person to grow up digital. As the behaviorists, cognitivists and constructivists posit, (see review above), how one spends one's time during childhood and adolescence shapes one's brain. Accordingly, since Digital Natives have grown up working with computers, electronic and digital tools, their brains have been wired differently from those of earlier generations. There is strong evidence suggesting that in fact, "Digital Natives are the smartest generation ever" (Tapscott, 2009, p.30). Research data do not support the negative criticisms and skepticisms made about Digital Natives such as: 'they are selfish, ill mannered, greedy, intolerant and narcissistic, with unrealistic expectations. Companies, institutions and nations succeeding today are those which are listening to the Digital Natives. As educators we should listen to them because this will enable us to envision and enact the new pedagogical principles and practices required for effective teaching in the 21 st century.

We learn from Kelly, McCain and Jukes' explanation of what they call TTWWADI (That's The Way We've Always Done It) that there is a mismatch between our understanding of how to share information and construct meaning as adults and that of Digital Natives. Given this understanding, if we uphold Piaget's (1923) proposition that "The principle goal of education is to create men and women who are capable of doing new things, not simply of repeating what other generations have done", then we should abandon teaching the old way and instead embed digital tools in our teaching and curriculum so Digital Natives can construct academic knowledge in a way they find more natural and convenient, rather than replicate our old ways.

As Tapscott (2009, p. 134) advises, "Schools should be places to learn not to teach". In the old model, students went to school to be fed information they did not know. It all came from one fountain of knowledge - the teacher. Today, however, Digital Natives can easily find the information they are looking for in an instant by surfing the web. What is needed to help them learn is to give them opportunities to learn how to navigate the digital world and find the relevant information, show them how to analyze it and critically evaluate it.

It is my view that the Digital Natives in our classrooms, as well as their Digital Immigrant parents, expect us to teach using the tools that the Digital Natives understand, are familiar with and prefer to communicate with. If we stick to the TTWWADI paradigm, we will not meet these expectations. It would be unrealistic, and possibly unwise, to expect that Digital Natives will be taught, learn and be assessed using approaches that were used when we (Digital Immigrants) went to school. The cultural generation gap would mitigate the effectiveness of that approach. Therefore, we need to educate ourselves so that our pedagogical practices will employ tools and speak the language that the Digital Natives understand best: - that is digital fluency of the $21^{\text {st }}$ century. Teaching along the TTWWADI approach is no longer educationally sound or effective in the $21^{\text {st }}$ century classroom of Digital Natives. Therefore, to be effective pedagogues in the $21^{\text {st }}$ century classroom, we need to embed digital technologies in all our pedagogical practices - teaching, learning, assessment and curriculum. Transitioning from the TTWWADI paradigm to Teach The Way Digital Natives Learn (TTWDNL) (and want to be taught) will not be easy because old habits are difficult to overcome. Such habits are often grounded in the unrealistic fear that moving from the TTWWADI to the TTWDNL paradigm might make the skills of Digital Immigrant teachers obsolete in classrooms of the digital age 
and render those teachers redundant. Moreover, the move represents a paradigm shift to a new way of teaching and most people simply resist change. However, as Peter Cochrane (2010, p. 57) rhetorically asks, can we "imagine a school with children that can read and write, but where there are many teachers who cannot"? The obviously negative response to this rhetorical question affirms that for us pedagogues, learning, developing and applying $21^{\text {st }}$ century technologies and fluencies, are essential strategies of being or becoming an effective pedagogue for the Digital Natives. As Dewey (1859 - 1952) put it, long before the digital age, 'If we teach today's students as we taught yesterday's, we rob them of tomorrow'. We rob them of tomorrow because we fail to equip them with the core set of skills that they need to survive in today's workplace and for their lifelong learning and productive citizenship. As Bill Gates' (2005) quote above says, training the workforce of tomorrow with the high school of today is using the wrong tool for the times. Some people may be slow in their response to change or remain stuck in their old TTWWADI ways and oblivious to change but this change should be welcomed because it is good, not only for our Digital Natives but for us teachers too. It might be initially resisted but it is inevitable. The paradigm shift from TTWWADI to TTWDNL is no longer an option. It is an imperative.

\section{References}

Barufaldi, J. (2002). The 5E instructional model. Paper presented at the Eisenhower Science Collaborative Conference, Austin, Texas, July 2002.

Bransford, J. D, Brown, A. L. \& Cocking, R. R. (2000). How people learn: Brain, mind, experience, and school. Washington, DC: National Academy Press.

Bruner, J. S. (1960). The process of education. Cambridge, MA: Harvard University Press.

Bruner, J. S. (1966). Toward a theory of instruction. Cambridge, MA: Belkapp Press.

Bybee, R.W., Taylor, J.A., Gardner, A., Van Scotter, P., Powell, J.C., Westbrook, A.\& Landes, N. (2006). The BSCS 5E instructional model: Origins, effectiveness, and applications. Colorado Springs BSCS, Accessed on 31 December 2013 online at http://www.bscs.org/curriculumdevelopment/features/bscs5es.html

Clarke, J. (1994). Pieces of the puzzle: The jigsaw method. In Handbook of cooperative learning methods, Ed. S. Sharan, Westport, CT: Greenwood Press, pp. $34-50$.

Cochrane, P. (2010). A shift to whole-mind instruction. In I. Jukes; T. McCain \& L. Crockett. Understanding the digital generation: Teaching and learning in the new digital landscape. Hawker Brownlow Education, Moorabin, Australia., Ch.7. pp.57- 78 .

Fullan, M. (2001). The new meaning of educational change. New York: Teachers College Press.

Gagne, R. M. (1977). The conditions of learning. New York: Holt, Rinehart and Winston.

Gates, B. (2005). What's wrong with U.S. High Schools - And how we can make them better. Talk presented at the National Summit on High Schools, Washington, DC, February 26.

Harris, K. R. \& Graham, S. (1999). Making the writing process work. New York: Brookline Books.

Howell, J. (2012). Teaching with ICT: Digital pedagogies for collaboration and creativity. Oxford University Press, Melbourne.

Jukes, I; McCain, T. \& Crockett, L. (2010). Understanding the digital generation: Teaching and learning in the new digital landscape. Melbourne, Vic: Hawker Brownlow Education.

Jobrack, B. (2013). The 5E instructional model: Engage explore explain evaluate extend.

From Science, Technology, Engineering and Mathematics. Accessed on 23 September 2013 at https://www.mnheonline.com/secondaryscience.pdf

Kagan, S. (1988). Cooperative learning: Resources for teachers. University of California: Riverside Books.

Kelly, F. S; McCain, T. \& Jukes, I. (2009). Teaching the digital generation: No more cookie-cutter high schools. Melbourne, Vic: Hawker Brownlow Education.

Marsh, C. (1996). Handbook for beginning teachers. South Melbourne: Longman.

McNierney. D. (2004). Case Study: One teacher's odyssey through resistance and fear. TechTrends, (48)5, pp. 64 68. http://dx.doi.org/10.1007/BF02763533

Mishra, P. \& Koehler, M. (2006). Technological pedagogical content knowledge: A framework for teacher knowledge. Teachers College Record, 108(6), 1017-54. http://dx.doi.org/10.1111/j.1467-9620.2006.00684.x 
National Research Council-NRC. (1999). How people learn: Brain, mind, experience, and school. Ed. J.D. Bransford, A. L. Brown, \& R.R. Cocking, Washington Dc,: National Academic Press.

Piaget, J. (1923). The language and thought of the child. (Translated M. Gabain). London: Routledge \& Kegan Paul. Piaget, J. (1950). The psychology of intelligence. New York: Routledge.

Piaget, J. (1954). The Construction of reality in the child. New York: Basic Books. http://dx.doi.org/10.1037/11168-000

Piaget, J. (1971). Science of education and the psychology of the child. New York: Viking Press.

Prensky, M. (2001a). Digital natives digital immigrants part 2: Do they really think differently? On The Horizon, 9(6), 3 - 16. http://dx.doi.org/10.1108/10748120110424843

Prensky, M. (2001b). Digital natives, digital immigrants part 1. On The Horizon, 9(5), 3 - 6. http://dx.doi.org/10.1108/10748120110424816

Sabelli, N. (2008). Constructionism: A new opportunity for elementary science education. DRL Division of Research on Learning in Formal and Informal Settings, 2008, p. 196. Available online at http://nsf.gov/awardsearch/showAwards.do? Award Number $=8751190$.

Skinner, B. F. (1953). Science and human behavior. New York: Macmillan.

Tanner, K. D. (2010). Order matters: Using the 5E model to align teaching with how people learn. Life Science, Volume 9, $159-164$.

Tapscott, D. (1997). Growing up digital. New York: McGraw-Hill.

Tapscott, D. (2009). Grown up digital: How the net generation is changing your world. New York: McGraw-Hill.

Taylor, F. W. (1910). The principles of scientific management. North Carolina: National Humanities Centre.

Vonnie, M. (2010). The 5Es powerpoint. Accessed online at https://www.robeson.k12.nc.us/cms/lib6/The5Es on 31 December 2013.

Vygotsky, L. S. (1929). The problem of the cultural development of the child. Journal of Genetic Psychology, Volume $36,415-434$.

Vygotsky, L. S. (1978). Mind in society: The development of higher psychological processes. Cambridge, MA: Harvard University Press. 